PontIFícIA UNIVERSIDADE CATÓLICA DO RIO DE JANEIRO

\title{
Uma Nova Perspectiva de Varejo no Saara
}

Fernanda Blumberg

Trabalho de Conclusão de Curso

Centro de CIÊnCIAS Sociais - CCS

DEPARTAMENTO dE AdMINISTRAÇÃO

Graduação em Administração de Empresas 


\title{
Fernanda Blumberg
}

\section{Uma Nova Perspectiva de Varejo no Saara}

\author{
Trabalho de Conclusão de Curso
}

Trabalho de Conclusão de Curso, apresentado ao programa de graduação em Administração da PUC-Rio como requisito parcial para a obtenção do título de graduação em Administração.

Orientadora: Claudia Soares

Rio de Janeiro

Novembro de 2016. 


\section{Agradecimentos}

Ao meu avô e fundador da Dimona, Seweryn Blumberg, pois a Dimona é o que é hoje devido à sua luta. Também gostaria de agradecer à minha avó Sarina Blumberg, que esteve ao seu lado até nos momentos mais difíceis, fazendo o melhor para nossa família, com muito amor. Mesmo não estando mais presente entre nós, tenho certeza de que meu avô estaria muito feliz e orgulhoso ao acompanhar minha formatura e conhecer este estudo sobre a empresa que ele fundou, sempre superando diversos desafios.

À minha família, minha mãe, meu pai, meu irmão e minha irmã, por terem me apoiado, estarem sempre ao meu lado e por terem me proporcionado frequentar as melhores escolas. Hoje sou quem sou graças a vocês.

À minha orientadora, Claudia Soares, por ter me dado o melhor suporte ao longo desses meses, com importantes incentivos e correções semanais. 


\section{Resumo}

Blumberg, Fernanda. Soares, Claudia. Uma nova perspectiva de varejo no Saara. Rio de Janeiro, 2016. 53p. Trabalho de Conclusão de Curso Departamento de Administração. Pontifícia Universidade Católica do Rio de Janeiro.

O presente estudo tem como foco a empresa familiar Dimona, uma empresa de malharia e estamparia que atua no setor de varejo no Rio de Janeiro. A problemática deste trabalho foi encontrada quando a companhia abriu uma nova loja e não conseguiu promover nenhum vendedor para o cargo de gerente, levando a empresa a contratar uma pessoa do mercado para ocupar esse cargo. Diante disso, o objetivo deste estudo foi compreender as lacunas e desafios do processo de treinamento de funcionários da área de vendas, observando que o fato de a empresa não ter uma estrutura de treinamento contínua afeta a capacitação dos funcionários para assumir novos cargos. Além disso, este trabalho também argumenta que estabelecer um programa de treinamento é fundamental para aumentar a motivação dos funcionários, evitar desperdícios e incrementar o lucro da empresa. Na análise do problema, utilizou-se a teoria de Abordagem Sistêmica de Treinamento de Bohlander \& Snell (2009). Para tanto, foram realizadas entrevistas com diretores, gerentes de loja e a coordenadora de Recursos Humanos da empresa, com objetivo de delimitar dificuldades de um programa de treinamento. A partir disso, foi estruturado um plano de treinamento para superar problemas encontrados pela empresa Dimona.

\section{Palavras-chave:}

Varejo, Saara. Práticas de Recursos Humanos, Treinamento e Desenvolvimento. 


\section{Abstract}

Blumberg, Fernanda. Soares, Claudia. Uma nova perspectiva de Varejo no Saara. Rio de Janeiro, 2016. 53p. Trabalho de Conclusão de Curso Departamento de Administração. Pontifícia Universidade Católica do Rio de Janeiro.

This work analyses Dimona, a knitting and printing family company, established in the city of Rio de Janeiro in 1967 and acting in the city's retail business. The problematique of this article aroused from the difficulty to promote a salesperson to the position of manager in a new store, leading the company to hire an outside person only to fill that position. In light of the before mentioned problem, this work aims at understanding the gaps and challenges of the company's employee designated training program, allowing us to infer that since the company does not hold a continuous training plan, the capacity of employees taking new positions is directly impacted. Moreover, this article argues that it is interesting to establish a training plan in order to increase employee's motivation and company's efficiency, hence increasing profit. The Bohlander \& Snell's (2009) Systemic Approach to Training's Theory provided the analytical tools to analyse the research problem. Furthermore, this work carried out interviews with company's directors, store managers and the Human Resources coordinator, in order to delineate general difficulties of the training program. In the end, this work proposes a training plan fixing the problems encountered during the interviews, arguing that a training process is relevant and necessary to overcome these difficulties.

\section{Key-words:}

Retail, Saara. Human Resources. Training and Development. 


\section{Sumário}

1. Introdução 8

2. Contexto e a realidade investigada 12

3. Diagnóstico da situação - problema e/ou oportunidade 18

4. Análise da Situação-Problema e propostas inovação/intervenção/recomendação 28

4.1 Treinamento para os novos funcionários e reciclagem para os antigos $\quad 28$

4.2 O treinamento oferecido pela Dimona é suficiente para o funcionário desenvolver a sua função 29

4.3 Desempenho da equipe e o processo de Feedback 29

4.4 Impacto do treinamento no resultado da empresa e na motivação dos funcionários 30

4.5 Sugestões para aprimorar o treinamento 31

5. Conclusões e Contribuição Tecnológica/Social 37

6. Referências Bibliográficas 40

7. Anexo $1 \quad 43$

8. Anexo $2 \quad 44$ 


\section{Lista de Figuras}

Figura 1: Organograma da empresa Dimona.........................................14

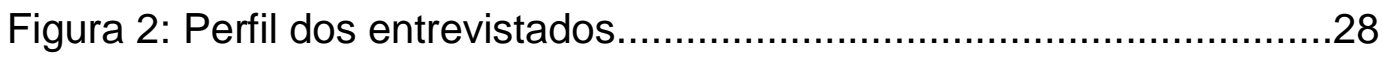




\section{Introdução}

De acordo com a pesquisa "Estratégias para o varejo brasileiro - Reflexões sobre os anseios do consumidor", realizada pela Deloitte em 2010, o consumidor está cada vez mais informado, exigente e consciente. Ele não se preocupa somente com a qualidade do que compra, mas com a forma como os produtos são feitos e se de fato são sustentáveis. A internet facilitou o acesso a informações variadas, fazendo com que as pessoas tenham maior conhecimento sobre o produto antes da compra, exijam mais qualidade, serviços de excelência e melhor atendimento.

Para acolher esse novo consumidor, os varejistas precisam de um modelo de atendimento e gestão de capital humano com foco no cliente, por meio de práticas de conceitos administrativos, como Treinamento e Desenvolvimento, Programas de Recompensas e Planos de Remuneração. Segundo essa mesma pesquisa da Deloitte, que contou com respostas de 50 empresas, observou-se que $82 \%$ das organizações possuem programas de desenvolvimento; 66\% de gestão de desempenho; $56 \%$ contam com sistema de recompensa; e 52\% realizam programas de reconhecimento. Os índices demonstram uma tendência à prática de políticas de recursos humanos, o que pode levar players que ainda não as adotam a repensar sua gestão, visando à evolução de sua posição no mercado.

Desse modo, em um segmento dedicado a aperfeiçoar sua mão de obra e que se depara com um consumidor mais exigente, estruturar uma equipe de vendas no setor de varejo é um desafio cada vez maior. Outra barreira tem a ver com o perfil do vendedor. Por se tratar de um trabalho que não requer nível de ensino superior, é mais difícil encontrar os funcionários ideais, sendo comum aparecerem candidatos sem as habilidades técnicas e comportamentais necessárias para o cargo. Nos casos em que as empresas encontram profissionais melhores, porém, muitos acabam trocando o emprego por outro mais atraente em pouco tempo.

Não à toa o setor varejista é marcado por um "turnover" alto. Conforme dados da Ibevar, por exemplo, esse número foi em média 54\% em 2014, o que pode ser compreendido também como um reflexo da desmotivação dos funcionários. 
Nesse contexto, este trabalho pretende estudar o caso da Dimona. Essa empresa familiar de malharia e estamparia, da área de vestuário, está no mercado há mais de três décadas e começou sua história no Saara, tradicional centro de comércio do Rio de Janeiro. Atualmente possui seis lojas físicas na cidade (quatro no Saara, uma em Copacabana e uma na Barra). A empresa conta ainda com atendimento via call center e um centro de distribuição em Caxias, onde se encontram diversos tipos de estamparia, como silk screen, silk automático, silk digital e o estoque.

Hoje o departamento de Recursos Humanos da organização dispõe de uma pessoa responsável por contratação, que em conjunto com o coordenador de vendas estruturou o treinamento dos novos funcionários - voltado para produtos e as técnicas de estamparia. Em relação a "feedback", a assistente de marketing e a responsável pelo "design" das lojas contribuem para a avaliação dos funcionários, uma vez que são presenças constantes nos pontos de venda.

Diante dessa infraestrutura, nota-se que a Dimona precisa investir no desenvolvimento da gestão de pessoas para continuar a crescer, o que deve ser realizado por meio da implementação de políticas de Recursos Humanos e a partir deste estudo poderá identificar a ação mais adequada.

Para muitos líderes, no entanto, essas práticas significam despesa e perda de tempo, o que pode ser até factível quando o treinamento é feito de forma errada, abordando temas inadequados para determinado grupo, fora de contexto e sem planejamento. No entanto, uma empresa que estuda as competências e habilidades necessárias consegue aprimorar de forma significativa sua equipe, fazendo com que treinamento e desenvolvimento sejam encarados como investimento, em vez de gasto.

Segundo Lacombe (2005), as empresas que não treinam e não desenvolvem seus funcionários podem encontrar dificuldades, seja pela falta de preparo dos colaboradores ou pela falta de conhecimento do negócio, causando danos à companhia.

Para Ivancevich (2008), Treinamento e Desenvolvimento são processos com o intuito de capacitar seus funcionários, por meio de informações, compreensão da organização e suas metas. Além disso, proporcionar um melhor entendimento dos objetivos do funcionário dentro da empresa faz com que seu atendimento melhore, seja mais reconhecido pela gerência e traga 
mais lucros. Esse tipo de capacitação deve ser feito não só com funcionários novos, mas com todos os colaboradores.

Por outro lado, é verdade que treinamento e desenvolvimento não estão imunes a riscos, como a saída das pessoas treinadas. O resultado é que a empresa investe na formação de um funcionário, agrega conhecimento à sua vida profissional e ele ainda poderá utilizar a nova experiência a serviço da concorrência. Segundo Lacombe (2005), essa é uma das razões pelas quais as empresas investem menos do que deveriam em treinamento. Outra razão apontada é a dificuldade de calcular o retorno, pois esse cálculo só pode ser feito no longo prazo.

Para reduzir os riscos, baseando-se na premissa de Ivancevich (2008), deve-se buscar treinar a equipe toda, diluindo assim os benefícios do investimento e diminuindo os riscos da perda - ou seja, mesmo que alguns saiam, outros vão ficar e aplicar o que aprenderam. Se em último caso for necessário escolher um grupo menor, ou apenas uma pessoa, é importante levar em conta a entrega de resultado, o tempo de casa e a identificação com a empresa. É importante também traçar um plano de desenvolvimento, mostrando para o colaborador a possibilidade de crescimento na companhia.

Diante das dificuldades apontadas e tendo como foco a Dimona, o presente trabalho pretende descrever e mapear os treinamentos mais adequados para o desenvolvimento dos funcionários da área de vendas. Nesse sentido, serão abordados os diferentes tipos de capacitação, conforme a área de atuação, a fim de enxergar onde há maior necessidade de desenvolvimento.

Para ajudar nessa tarefa, realizou-se uma pesquisa exploratória de natureza qualitativa com os gerentes e os diretores da empresa. A intenção foi levantar alternativas de melhoria na capacitação dos funcionários da área de vendas.

Acredita-se que este trabalho será fundamental, pois a definição de uma política de treinamento vai colaborar para o crescimento dos funcionários dentro da empresa, além de motivá-los. Também permitirá à diretoria perceber a importância do RH, contribuindo para estruturar ações, encontrar lacunas e entender melhor a organização como um todo.

No mais, o presente estudo possui um caráter significativo para a autora, já que ela faz parte desta empresa familiar e conhece de perto os esforços para alcançar a atual posição da Dimona no mercado. Com esta análise, a autora pretende aumentar o conhecimento sobre a 
companhia, a fim de começar sua trajetória dentro da Dimona; compreender em maior profundidade os pontos fortes e fracos da empresa, bem como contribuir para a melhoria contínua.

Portanto, o pressuposto do trabalho é que com o devido treinamento haverá uma melhora no clima organizacional, na identificação do empregado com a marca e com os produtos e, consequentemente, nas vendas e na retenção de colaboradores. 


\section{Contexto e a realidade investigada}

Neste capítulo, será apresentado o estado da arte do objeto de estudo em questão: a empresa Dimona. Isso inclui descrever o desenvolvimento e a atuação da empresa no mercado, considerando a consolidação do setor de varejo. Esse tipo de abordagem ajudará a apontar as complexidades e desafios que a empresa enfrenta hoje para que, posteriormente, consigamos propor estratégias de melhoria.

Segundo Luís Fernando Varotto (FGV-EAESP, 2006), a história do varejo no Brasil começou com as formações populacionais nas primeiras vilas litorâneas, tendo como principal mercadoria o açúcar. O comércio nessa época se restringia aos empórios de importação de escravos e manufaturas e de exportação de açúcar, depois a ouro e pedras preciosas. Muitos anos se passaram até a modernização urbana e a industrialização. Com o rápido crescimento populacional e a carência de alimentos nos grandes centros urbanos, as feiras livres apareceram para facilitar a distribuição dos gêneros de primeira necessidade, reduzindo os intermediários e o custo dos produtos.

Ao longo dos anos, o varejo foi se modernizando e sofisticando, assim surgindo as primeiras lojas de departamento no Brasil. Essa tendência foi inspirada no "american way of life", expressão que se refere ao estilo de vida americano do início do século XX, possibilitado nos EUA pelo consumo desenfreado e alto crescimento da economia. Com o milagre econômico brasileiro em 1970, apareceram os primeiros hipermercados no país e, após alguns anos, os primeiros shoppings centers. Para Varotto:

"o varejo teve mudanças que foram vertiginosas nos últimos setenta anos e tem se mostrado capaz de incorporar velozmente as mudanças tecnológicas que têm levado o setor a recriar-se continuamente. O futuro certamente reserva surpresas ainda maiores" (Varotto, 2006, p.90).

Hoje, o varejo tem um cenário complexo, pois é um mercado que cresce e tem um papel muito importante na economia. De acordo com o Instituto para Desenvolvimento do Varejo (IDV), esse mercado é o maior gerador de empregos no país e ao longo do tempo vem crescendo bastante - representando, por exemplo, cerca de 33\% do PIB em 2013, de acordo 
com Arthur Motta (GS\&MD). Já segundo dados do IBGE, em fevereiro de 2016, $19 \%$ da população do Brasil trabalhava com comércio, varejo e reparo de veículos, indicando ser o setor mais ocupado entre os brasileiros.

Apesar de o varejo enfrentar um ano difícil para as vendas, em abril de 2016, por exemplo, houve crescimento, de acordo com o IBGE. Comparado a outros anos, contudo, as vendas em geral têm caído bastante. Em 2015, recuaram 4,3\%, ainda conforme as informações do IBGE - pior resultado desde 2001. Esses indicadores são reflexos da crise econômica no país, devido à redução de renda das famílias, ao crédito mais restrito e à inflação alta, como aponta Robson Sales (2016). Mesmo que as vendas estejam caindo, o varejo influencia bastante a economia, devido à empregabilidade, sua possibilidade de gerar renda e de proporcionar benefícios aos clientes, produtores e atacadistas.

De acordo com entrevista feita pela Revista Exame com o presidente da Riachuelo, Flavio Rocha, a cada quatro pessoas, uma é empregada pelo varejo. Rocha ainda afirmou que nos últimos anos o PIB cresceu 40\%, mas o varejo cresceu três vezes mais. Já as redes de bens semiduráveis, principalmente as de roupa, cresceram 500\%. O entrevistado ressaltou também que o principal vetor de transformação da economia é o varejo, com seus sistemas de crédito e crediários, propiciando poder aquisitivo aos consumidores.

Atualmente existem em torno de 9 milhões de micro e pequenas empresas, que empregam 52\% da mão de obra formal do país. São essas as maiores geradoras de renda no comércio, já que representam 53,4\% do PIB do setor, segundo o Sebrae (SEBRAE, 2014).

É nesse ambiente bastante competitivo que a Dimona atua. A empresa foi fundada por Seweryn Blumberg, que chegou ao Brasil em 1948, fugindo da Segunda Guerra Mundial. Ele começou a carreira como mascate e alguns anos depois foi trabalhar na loja de cama, mesa e banho de seus cunhados, no Saara. Em 1967, abriu o próprio negócio na região, sua primeira loja, que se chamava Blumtec. Nessa época, a loja era especializada em confecção feminina e tinha como principal público as "sacoleiras", como eram conhecidas as vendedoras de porta em porta.

Em 1979, Eduardo Blumberg, filho mais velho de Seweryn, começou a trabalhar com o pai, ajudando na abertura da segunda filial, também no Saara. Nesse momento, além de venderem roupas femininas, as lojas comercializavam mercadorias da Hering e calça jeans. Em 1983, chegou a vez de o filho mais novo ingressar na empresa, tornando-se mais uma 
pessoa da família a ajudar na gerência das lojas. Quatro anos depois, foi aberta a terceira filial, que tinha foco diferente das outras, pois se tratava de uma loja que vendia camisetas estampadas e materiais de silk screen - telas de madeira com tintas específicas para estampar camisetas. Foi a partir desse momento que começaram a se especializar em malharias e nomearam as lojas de Dimona.

Em 2002, começaram a se especializar em estamparia, quando acrescentaram novos tipos de estamparia em suas lojas, como copiadora e bordado. Não muito tempo depois, investiram no silk digital e foram a primeira loja no Brasil a fazer uso dessa máquina em serviços prestados diretamente para o cliente - que podia chegar, escolher a estampa e encomendar a camiseta na hora. Em 2008, com a terceira geração da família na empresa, as lojas e produtos foram modernizados, iniciando então a fase dos licenciamentos para grandes eventos, com direito de uso da marca e logo dos eventos.

Agora, em 2016, a Dimona conta com quatro diretores que são membros da família, responsáveis por gerir o negócio, e tem em torno de duzentos funcionários, entre vendedores, gerentes, responsáveis pela área de TI, entregadores, estoquistas e prensadores.

A Figura 1, a seguir, apresenta a estrutura organizacional da empresa:
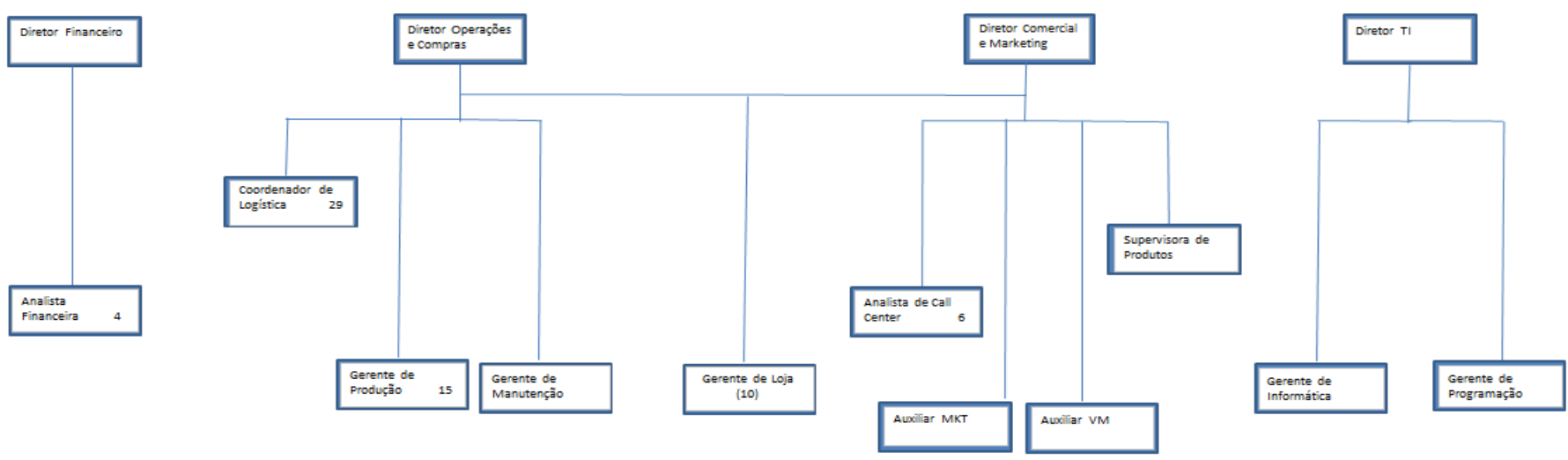

(Figura 1 - Organograma da empresa Dimona)

O diretor-financeiro e sua equipe, composta por quatro pessoas, são responsáveis por toda a parte administrativa e do departamento pessoal. As tarefas são divididas entre a coordenadora e suas assistentes, sendo suas principais atribuições contas a pagar, contas a receber, folha de pagamento, férias e crédito/cobrança. Há ainda a ajuda de dois portadores, que vão ao banco e buscam documentos quando necessário. Já o Diretor de TI tem a ajuda de 
duas pessoas: o programador e o analista de informática, responsáveis pelos projetos on-line, os sites com produtos das marcas licenciadas, o e-commerce, a intranet e o atendimento ao cliente.

O diretor-comercial/marketing e sua equipe, formada por uma gerente de produto, auxiliar de marketing e auxiliar de visual merchandising, são responsáveis pelas mercadorias que a loja oferece, a forma como são expostas e a maneira como os clientes ficam sabendo dos novos produtos, além de conduzirem toda a parte de licenciamento. Essa diretoria também cuida do atendimento via call center e dos gerentes das lojas. A analista de Recursos Humanos, inclusive, reporta-se diretamente à área.

Os gerentes das lojas são responsáveis pelos vendedores e desenhistas, cuidando para que a arte do cliente esteja no formato e tamanho corretos para serem estampados pelo operador de máquina (a pessoa que estampa na camisa). Também conferem o trabalho dos operadores de caixa, dos empacotadores (responsáveis por entregar o produto finalizado ao cliente), dos repositores (que têm a função de ver quais produtos estão terminando nas lojas e solicitar novas remessas ao Centro de Distribuição), bem como dos fiscais de loja.

O diretor de Operações e Compras também conta com uma equipe que o auxilia na distribuição de produtos e serviços. No grupo, há um gerente de logística, responsável por garantir que todas as lojas possuam todos os produtos ofertados pela empresa. Além disso, esse trabalho demanda a eficiência dos estoquistas de cada loja, sem esquecer os supervisores de estoque. Os supervisores são responsáveis pelas entregas, certificando-se de que os estabelecimentos estejam recebendo as mercadorias do Centro de Distribuição.

O gerente de produção tem como função acompanhar o processo das camisas a serem estampadas por silk screen. Esse processo se inicia com a finalização de uma arte para impressão no tecido da camisa. Nesse momento, deve-se observar o trabalho de separação de cores da estampa para a revelação de telas (matrizes), visto que para cada cor de estampa é gerada uma tela matriz. Por meio de um rodo puxador, a tinta é colocada sobre a tela, que molda a passagem da tinta para a camisa, constituindo o formato da estampa pretendida. Esse tipo de procedimento demanda profissionais de estamparia e auxiliares. Ainda, os gerentes de produção, os gerentes de loja e os responsáveis pelas manutenções das lojas também se reportam ao diretor de Operações e Compras. 
A Dimona tem como missão fundamental estar presente na vida das pessoas, por meio de camisetas e de sua personalização, ajudando a contar pequenas e grandes histórias. A empresa também marca presença em grandes acontecimentos da cidade e do país, sendo licenciadora oficial de grandes eventos, como Rock in Rio (2011, 2013 e 2015); JMJ Rio 2013; Blocos de Carnaval, como Bola Preta, Monobloco e Sargento Pimenta; Porta dos Fundos; os Jogos Olímpicos e Paralímpicos 2016.

Com o propósito de ser líder no mercado, a Dimona vem investindo ao longo dos anos em diferentes e avançadas técnicas de estamparia, além de oferecer a mais completa linha de camisetas, abrangendo diferentes preços, tecidos, acabamentos e lavagens. Seu objetivo é muito importante: garantir a transformação de uma ideia em uma estampa, com excelente qualidade.

Assim, é uma empresa que atende diversos públicos com a venda de camisa branca simples ou de camisas estampadas, customizadas pelo cliente.

Hoje, são 43 pessoas que ocupam o cargo de vendedor, sendo apenas 6 homens. A idade varia de acordo com o perfil da gerência de cada loja. Por exemplo: as lojas de Copacabana e Barra contratam pessoas a partir de 25 anos. Já as lojas do Centro chegam a contratar pessoas com 40 anos ou mais. A grande maioria dos vendedores é formada por pessoas casadas e com filhos. Atualmente para a contratação é um pré-requisito ter concluído o Ensino Médio. Considerando funcionários há trinta anos na empresa, porém, alguns não têm formação completa.

A loja de Copacabana foi aberta no início de 2016 e nesse exato momento a gestão percebeu que algo errado estava acontecendo: a empresa não conseguiu promover nenhum funcionário para o cargo de gerente, mesmo contando com gente há muito tempo na casa. Para solucionar esse problema, foi contratada uma pessoa do mercado para preencher o cargo, em um caso que será detalhado mais adiante, no capítulo 3. A partir da dificuldade de promoção interna, observou-se que algo dentro da Dimona precisava ser reestruturado para motivar e treinar os funcionários, o que remete naturalmente a programas de capacitação.

$\mathrm{O}$ desenvolvimento das equipes é essencial e se faz ainda mais importante pela variedade dos produtos da empresa. A Dimona trabalha com diversos tipos de malhas, diferentes tipos de produção, camisas com texturas distintas, modelos variados de estampa. Tudo isso demanda uma atualização frequente, que possibilite aos funcionários conhecerem 
as peculiaridades dos produtos e esclarecerem corretamente as questões do consumidor no dia a dia. No mais, ter o hábito de treinar os empregados faz com que os bons evoluam e se sintam motivados e desafiados (Lacombe, 2005).

Hoje a Dimona promove apenas um treinamento inicial para os novos funcionários sobre a empresa e seus produtos. Não há, portanto, nenhum processo de reciclagem ou atualização.

O investimento em treinamento é interessante, pois, de acordo com Gil (2001), o treinamento é forma pela qual se adequa o funcionário ao seu cargo. Não apenas dando conhecimentos e habilidades para atuar, mas propiciando uma formação básica com o intuito de modificar antigos hábitos. No caso da Dimona, isso se revela de grande importância, pois muitos funcionários trabalham lá há bastante tempo e não têm vontade de mudar o que estão acostumados a fazer. Esses treinamentos visam, portanto, à alteração de uma percepção fatigada e são capazes de transformar visões ultrapassadas.

Isso quer dizer que não basta o vendedor estudar e buscar informações sobre o que está vendendo. Do funcionário mais novo ao mais antigo, todos precisam de um treinamento contínuo e de "feedback", para assim melhorar seu trabalho. De acordo com Gil (2001), a atenção individual pode ser bastante eficiente e promover mudanças comportamentais.

$\mathrm{Na}$ Dimona, até existe um responsável pela supervisão das lojas, tanto do espaço físico quanto das pessoas, ajudando os vendedores a alinharem metas e entenderem suas expectativas por meio de feedbacks. Contudo, a dificuldade em promover colaboradores e manter bons funcionários pode estar atrelada a outros fatores, como a falta de liderança da gestão, falha na contratação, problemas com o clima organizacional e falta de identificação com a empresa, de acordo com o gerente de marketing. 


\section{Diagnóstico da situação - problema e/ou oportunidade}

No início de sua especialização em malharia e estamparia, a Dimona tinha duas lojas no Saara. Até alguns anos atrás, as lojas funcionavam como duas marcas distintas, embora com oferta de produtos similares. Cada uma dessas lojas era administrada por um sócio diferente e tinha o perfil do seu respectivo gestor. Com o tempo, elas se transformaram em uma única marca, iniciando gradativamente um processo de expansão tanto no mercado têxtil quanto na indústria. Nesse período, começaram a ser feitos investimentos em maquinários, sistemas de gestão, consultorias, centro de produção e personalização. No geral, movimentos para que a empresa deixasse de ser uma loja e passasse a ser vista como uma indústria que tem loja.

Evidentemente, a partir do processo de expansão, surgiram oportunidades de abrir novas lojas. Assim, foram inauguradas mais duas no próprio Saara: uma focada em Silk Digital e a outra, no varejo. Nesse momento, iniciaram-se também os projetos de licenciamento, com camisas produzidas para os grandes eventos da cidade. E, na sequencia, veio a oportunidade de abrir lojas na Barra e em Copacabana.

A abertura das lojas realçou o problema de falta de um plano para os funcionários e de um projeto para formação de talentos. Por ser um negócio com produtos muito peculiares e técnicos, não adiantava contratar bons gerentes do mercado e colocá-los na empresa. Na loja de Copacabana, por exemplo, houve uma tentativa desse tipo de contratação. O profissional, porém, não conseguiu atuar exatamente como um gestor, pois não bastava que conhecesse as técnicas e o modo de operação da empresa, mas sim que tivesse maior experiência nesse setor tão específico. Além disso, o fato de a Dimona ser uma empresa familiar demanda uma compreensão de certas regras de funcionamento diferentes das demais organizações, havendo uma cultura que o gerente precisa conhecer antes de tomar a frente de uma loja.

O candidato que veio do mercado enfim não se adaptou e a solução encontrada foi promover um subgerente de outra loja. Não era a escolha ideal a princípio, visto que esse subgerente já tinha sido promovido antes sem sucesso. No entanto, dado o fato de a loja de 
Copacabana ter uma estrutura menor, compacta e mais focada no varejo, acreditou-se que o perfil do funcionário estaria mais de acordo. A boa notícia é que até o momento a opção tem dado certo. A má é que isso ocorre mais pelas características que o profissional por acaso já reunia do que necessariamente por um programa de treinamento estruturado

$\mathrm{Na}$ abertura de novas lojas no Saara, também foi constatado que não havia pessoas aptas para assumir o cargo de gerência. O caminho foi promover bons vendedores, só que isso igualmente trouxe dificuldades, pois um bom vendedor nem sempre é um bom gerente. No fim das contas, o que houve foi a perda de bons vendedores.

Hoje com seis lojas, a Dimona é percebida como um negócio diferenciado, justamente pela maneira de se reposicionar. A empresa não é mais vista como uma típica loja do Saara. Agora, ela é entendida como uma indústria que possui loja no mercado popular, e que tem também penetração mais profunda. Ainda assim, e como constata este capítulo, a empresa ainda não consegue acompanhar o desenvolvimento de seus colaboradores na mesma velocidade e qualidade que precisam.

Segundo o diretor-comercial, a falta de desenvolvimento está ligada a dois fatores principais: i) recrutamento e seleção; e ii) falta de um projeto constante de educação e treinamento. Embora já tenha havido um esforço de fazer algo focado em educação e cultura, as diferenças culturais e de percepção entre as gerações dos diretores dificultaram um trabalho contínuo nesse sentido. As gerações possuem visões diferentes sobre o negócio, fundamentadas em grande parte por percepções distintas do que significa investimento e custo para a empresa.

Neste trabalho, quando perguntado às gerações mais velhas sobre a cultura da Dimona, ficou evidente que muitos não viam valor naquilo que a geração mais jovem achava representativo, como o investimento a longo prazo em treinamento e capacitação de funcionários. O que para os mais jovens era investimento para os mais velhos simbolizava custos. No intuito de ilustrar esse cenário, vale destacar que, certa vez, um trabalho de capacitação não foi finalizado devido ao tempo consumido pelos projetos de licenciamento e uma discórdia entre os diretores.

Isso demonstra que a questão cultural da família e a grande diferença de pontos de vista acabam eventualmente "prejudicando" a execução de um plano de treinamento. Até porque esse plano não tem que vir apenas de baixo para cima, mas de cima para baixo. Sendo 
assim, não adianta implementar regras e processos na empresa se seus donos não querem ter nenhum tipo de metodologia estrutural - e ainda estão presos a modelos de dar ordens independentemente das regras.

Portanto, como podemos perceber, o problema encontrado vai muito além da falta de treinamento e desenvolvimento. De acordo com um dos diretores, também há uma falha no recrutamento, o que leva à contratação de pessoas sem o perfil e as habilidades adequadas para a evolução delas na empresa. Atualmente, a contratação de novos funcionários é feita por meio de currículos deixados nas próprias lojas da Dimona ou em sites, como o Rio Vagas. Quando um candidato se cadastra, a coordenadora de Recursos Humanos recebe um e-mail com a candidatura da pessoa e seu currículo. A análise do perfil do candidato, então, é feita um por um, apontando quais estão dentro do perfil da vaga e da loja.

Após a seleção dos currículos, uma reunião é agendada com o interessado. Nesse primeiro encontro, a pessoa preenche uma ficha, conversa sobre as experiências anteriores, escolaridade e a questão de viver longe do trabalho. Concomitantemente, a recrutadora conta sobre a empresa, os benefícios, remuneração e carga horária. Ainda nesse primeiro momento, no caso específico do candidato para área de vendas, pede-se que ele faça uma redação com temas como o que a venda pode trazer ao candidato, ou o que o motiva a ser vendedor - de forma a diferenciar e complementar o seu currículo.

Em seguida, a recrutadora analisa a redação e a entrevista. Sendo aprovado pelo RH, o candidato é chamado para a segunda etapa, realizada com o gerente da loja aonde a pessoa será encaminhada. Se aprovado pelo gerente, o candidato é contratado. Caso contrário, não é admitido e seu currículo é excluído do banco de dados.

Ao ser admitido pelo RH e pelo gerente da loja em que vai atuar, o novo funcionário passa por um treinamento para aprender sobre os procedimentos de estamparia oferecidos pela empresa, os tipos de malharia e suas diferenças, técnicas de abordagem e como usar o sistema de vendas. Para saber se o funcionário conseguiu aplicar na prática tudo o que aprendeu, os gerentes de cada loja passam o feedback para o coordenador de vendas, que avalia o que pode mudar ou aprimorar.

Uma desvantagem desse tipo de treinamento é que por estar na companhia de um vendedor mais antigo o novo funcionário pode ter acesso a determinados vícios e hábitos que 
não devem ser preservados, culminando no reforço desses desvios, o que é prejudicial à empresa.

Para amenizar esses impactos, segundo o coordenador de vendas responsável pelos treinamentos, também foi realizada uma reciclagem com os funcionários antigos. A ideia era unificar as informações e fazer com que todos os vendedores "falassem a mesma língua", já que não há um padrão de vendas e cada loja tem suas próprias regras, sem processos bem definidos. Em seguida, deveria ter sido feito um acompanhamento para mensurar os resultados, mas com a alta demanda dos eventos que a empresa licencia não foi possível acompanhar a evolução do trabalho. Mas esse não foi o único processo descontinuado. Infelizmente, por uma série de razões, como a falta de foco nesse tipo de projeto, desde o começo de 2016 a capacitação de novos funcionários não tem sido realizada.

Infraestrutura, todavia, não falta. A empresa tem salas que podem ser reservadas para esse tipo de reunião e materiais para guiar os treinamentos. Tudo elaborado pelo diretorcomercial, com a coordenadora de Recursos Humanos e o coordenador de vendas.

No que diz respeito à remuneração, os vendedores ganham 2,5\% em cima do total de sua venda, no período de 20 em 20 dias, enquanto os gerentes têm um salário fixo mais comissão (que varia conforme a loja). De acordo com o Sindicato do Comércio, o trabalhador não pode ganhar menos que novecentos e setenta e seis reais por mês. Então, caso algum vendedor não alcance uma remuneração acima desse valor, a empresa lhe pagará o mínimo. Este fato é comum ocorrer, principalmente com os novos vendedores, pois ainda estão em adaptação e treinamento, sem contar com clientes "fiéis", conquistados com o passar do tempo.

No início de todo mês, os vendedores recebem de seus gerentes suas metas diárias para os vinte dias seguintes. Se houver caso de atingirem quinze dias de meta - não necessariamente corridos - os vendedores têm direito a receber mais um percentual acima dos $2,5 \%$. Isso é chamado de superprêmio, e a estratégia por trás dessa política é motivá-los de forma a baterem suas metas e vender mais produtos.

Além disso, a empresa provê os seguintes benefícios: vale-transporte (obrigado por lei), plano de saúde (dado para os funcionários depois do período de experiência) e convênio com farmácias e supermercados por meio do cartão Good Card, concedido todo primeiro dia 
do mês e que disponibiliza um crédito de cento e oitenta reais, depois descontado no contracheque.

As práticas de Recursos Humanos são feitas em casos pontuais, como houve durante as Olimpíadas. Quando o vendedor atingia a meta proposta, poderia ganhar algum produto olímpico ou até bonificação, além de ser reconhecido pelo gerente diante da equipe. Em paralelo à competição individual, também houve um estímulo de competição por loja, o que significava dizer que o estabelecimento que vendesse mais os produtos olímpicos seria premiado com medalha de ouro e alguns brindes. Ao segundo lugar caberia a prata e ao terceiro o bronze. Evidentemente, o principal objetivo era motivar ainda mais o empenho dos vendedores e proporcionar condições para que cada um desse seu melhor para se destacar diante da equipe.

Outro fato interessante relatado pela coordenadora de RH é que há um ano e meio, no momento em que ela ingressou na empresa, o clima organizacional era bem ruim: muitos funcionários insatisfeitos, que faltavam muito ao trabalho ou até iam embora no meio do expediente. Para melhorar esse quadro, a coordenadora se mostrou mais presente e próxima dos funcionários, possibilitando que se sentissem mais acolhidos por alguém de dentro da empresa. Daí se percebe que no processo de recrutamento é essencial encaminhar o colaborador à loja em que seu perfil esteja mais de acordo, para que ele possa se sentir mais identificado com o trabalho e seus colegas. Tudo isso ajuda na melhora do clima organizacional, fazendo com que os funcionários se sintam mais integrados e identificados com a companhia.

Ainda assim, mesmo depois dessas medidas no âmbito do RH, a Dimona ainda está um tanto obsoleta em relação a como as empresas lidam com seus colaboradores. Para Lacombe (2005), o treinamento não deve ser feito uma única vez para os novos funcionários, mas ser algo contínuo nas organizações bem administradas. Além disso, não deveria ser uma escolha da empresa treinar ou não, pois as pessoas são admitidas com habilidades e técnicas genéricas. Logo, cabe à empresa treiná-las para estarem aptas a atuar dentro da organização.

Contudo, no caso da empresa estudada, ainda há uma dificuldade de enxergar a necessidade de treinar seus colaboradores - como evidenciado nas discordâncias entre gerações. Como afirma Welch: "o único trabalho do dono do negócio é desenvolver as pessoas. Se fracassar nisso, será o fim, pelo fato de não serem executivos que vão projetar um 
motor a jato, por exemplo" (Welch apud Lacombe, 2005). Nesse sentido, não serão os diretores que estarão assumindo as rédeas e orientando o ritmo no cotidiano das lojas, mas os seus colaboradores. Por isso, é necessário não apenas um processo seletivo mais aprimorado e consciente dos problemas já citados, mas, sobretudo, o investimento em treinamentos, que vão auxiliar a própria diretoria a implantar a cultura e o modo de atuação que deseja.

Para Chiavenato (2010), as pessoas constituem o principal patrimônio das empresas, por serem elas que fazem as coisas acontecerem. Logo, as pessoas são uma questão vital para o sucesso do negócio, sendo o principal diferencial competitivo das organizações. Nos últimos anos, a Dimona de fato cresceu bastante; porém, como visto anteriormente, o desenvolvimento das pessoas não correspondeu ao mesmo nível. Ou seja, caso a empresa tivesse investido em treinamento e desenvolvimento, poderia ter reduzido custos com a contratação de um novo gerente.

No Brasil, para cada cinco empresas, o tema "desenvolvimento de lideranças" é prioritário em quatro delas. E mais: $55 \%$ das organizações possuem um executivo sênior dedicado a treinamentos, tendo havido crescimento de $9 \%$ nos investimentos com capacitação, segundo dados da pesquisa ABTD (2013). Grandes empresas do mercado investem pesadamente em treinamento por terem um retorno muito satisfatório, de acordo com Chiavenato (2010). Essas empresas compreendem que treinar não é uma despesa, mas um investimento que traz muitos benefícios tanto na motivação dos colaboradores quanto no resultado final de vendas.

Ao descrever e mapear os tipos de treinamento mais adequados, este trabalho deseja mostrar como a empresa pode ter funcionários mais qualificados, maior satisfação dos clientes em relação ao atendimento e, consequentemente, maior rentabilidade. Para ter certeza que investir em treinamento e desenvolvimento trará benefícios no desempenho individual e organizacional, este estudo sugere a adoção da Abordagem Sistêmica de Treinamento de Bohlander \& Snell (2009), que envolve quatro fases. São elas: i) levantamento de necessidade, ii) projeto, iii) implementação e iv) avaliação. A seguir, descreve-se cada uma delas.

Na primeira fase, deve-se levar em conta se os funcionários não estão conseguindo atingir as metas, se a produção está abaixo do esperado e se há muitas reclamações de clientes. Esses, por exemplos, podem ser fatores para o RH perceber que precisa treinar os 
colaboradores. Para confirmar se o treinamento será favorável para a empresa, os gerentes devem analisar a empresa, as tarefas e as pessoas.

Precisam ser analisados o ambiente, as estratégias e os recursos, para determinar qual o foco do treinamento. A disponibilidade dos funcionários e o tempo exigido para treiná-los são outros fatores importantes. Também deve-se considerar o custo da mão de obra direta e indireta, bem como a qualidade do serviço. Cabe aos gerentes, aliás, perceber com eficiência quais tipos de treinamento serão melhores para a equipe. Ademais, é relevante analisar as tarefas, revisando-se a descrição e especificação dos cargos para identificar as atividades realizadas em cada. É necessário determinar ainda o conteúdo que será usado no programa de treinamento. Inclusive, é preciso avaliar as pessoas, para determinar quais indivíduos precisam de treinamento. No caso do presente trabalho, o foco são os vendedores.

Uma vez levantadas às necessidades e lacunas, a segunda fase reside na elaboração de um programa robusto de treinamento, sendo essencial entender qual tipo de ambiente vai favorecer e aumentar o aprendizado. A concepção do treinamento deve focalizar os objetivos instrucionais, prontidão e motivação dos treinados, princípios de aprendizagem e características dos instrutores.

Com os objetivos instrucionais, será possível desenhar os resultados desejados, descrevendo-se as habilidades ou conhecimentos a serem adquiridos e mudados. Ao mesmo tempo, o treinamento é influenciado pelas características dos instrutores: eles devem ser pessoas conscientes, orientadas para as metas e autodisciplinadas - visto que serão responsáveis por construir uma ponte entre a empresa e o funcionário.

Um bom treinador deve ter conhecimento do assunto, ser adaptável ao padrão da turma, possuir interesse no tema que está ensinando e aplicar as instruções de forma clara e entusiasmada. Esses são elementos fundamentais para que os funcionários tenham uma boa reação ao processo.

Após a avaliação das necessidades, dos objetivos instrucionais, prontidão e motivação dos funcionários, a empresa passará do foco em si própria para o foco nos funcionários. Nessa transição, é importante considerar os princípios de aprendizagem e as características de programas de treinamento que ajudem os funcionários a captar novos materiais, tanto em sua 
vida pessoal quanto profissional. O princípio de aprendizagem está relacionado com outros fatores, como:

- Estabelecer metas: para motivar os colaboradores nos treinamentos;

- Significado da apresentação: os treinamentos terem associação com algo relacionado ao dia a dia das pessoas, facilitando o aprendizado;

- Modelagem: usada para mostrar o comportamento que a empresa espera do funcionário, por meio de fotos, filmes, figuras, entre outros;

- Diferenças individuais: as pessoas aprendem em níveis e formas diferentes. Logo, o treinamento tem que considerar a diferença entre elas;

- Prática ativa e repetição: os treinamentos devem ter momentos de prática para que o funcionário tenha a oportunidade de executar suas tarefas do mesmo modo que faz em seu trabalho real;

- Período de aprendizagem: o tempo dedicado ao treinamento

- Feedback e reforço: ajudam a mostrar os resultados e a qualidade do desempenho da função, o que pode apontar a necessidade de reforço dos conceitos aprendidos.

Depois de elaboradas as primeiras duas fases, implementa-se, enfim, o programa de treinamento, no qual se define o melhor método de treinamento para a equipe. Uma alternativa pode ser o treinamento no local de trabalho, em que os funcionários recebem experiência prática com instrução de seu supervisor, ou outro treinador. Outra opção é o treinamento profissionalizante, no qual o funcionário recebe instruções e informações tanto no trabalho quanto fora dele, abordando aspectos práticos e teóricos de acordo com a função. Também existem outras possibilidades, como treinamento à distância, estágio e programa de Trainee.

Um método de treinamento não abordado por Bohlander \& Snell (2009) é o formal interno, programado e executado pela própria empresa, que pode ser feito com palestras, cursos, seminários de capacitação, entre outros, para desenvolver as pessoas nas funções que exercem. Esse tipo pode ser ministrado por profissionais da empresa ou contratados, cabendo à organização decidir o que é melhor. Acredita-se que a vantagem desse método é que ele é desenhado e desenvolvido para atender às necessidades específicas da empresa, o que 
possibilita treinamentos focados em atitudes e habilidades que os colaboradores precisam melhorar (Lacombe, 2005).

Depois dessas três grandes fases de implementação, é importante avaliar a efetividade do treinamento, o que pode ser feito por meio de critérios que auxiliam os gerentes a descobrirem as áreas problemáticas e o que deve ser mudado.

O primeiro critério de avaliação é a reação do funcionário. Considerado um método fácil, é o mais comum para estimar se o treinamento foi positivo ou não. Os colaboradores satisfeitos utilizarão com mais frequência o que aprenderam, tendo um comportamento e desempenho mais adequados. Os insatisfeitos, por sua vez, vão demonstrar maior insatisfação com o trabalho, estando mais desmotivados. Outro critério é o de aprendizado, em que a empresa testa os treinados antes e depois do treinamento, para ver se realmente absorveram o conteúdo ou a prática. O teste, aliás, pode ser feito por meio de grupo-controle, no qual apenas uma parte dos funcionários é treinada, sendo posteriormente comparada à parte que não teve acesso à capacitação. Assim, a empresa poderá concluir se o treinamento foi efetivo ou não.

Outro critério é o comportamento, que pode ser avaliado ao observar se o funcionário mudou suas atitudes e está aplicando na prática o que aprendeu durante o curso. Se ele não estiver usando as técnicas ensinadas, nem tiver mudado seu comportamento, pode ser um sinal de que o treinamento falhou.

Por fim, medir o resultado e o retorno do investimento é uma prática importante, pois é uma forma que o gerente de RH tem de identificar se o treinamento trouxe impactos, como maior produtividade, menor rotatividade, melhoria da qualidade, redução de custos e clientes mais satisfeitos. Para chegar a essa análise, o gerente de RH deve utilizar diversos dados, por exemplo: se as vendas aumentaram, recursos financeiros, informações de pesquisa com os funcionários e o grupo-controle. Além disso, deve considerar os custos do treinamento, com o objetivo de concluir se o benefício alcançado foi maior que o investimento na capacitação.

Inclusive, pode-se medir o resultado por meio do Benchmarking, que compara os próprios serviços e práticas de desenvolvimento com as práticas de líderes do mercado. Para usar esse método com sucesso, os gerentes devem definir de modo claro as medidas de competência e desempenho e avaliar a atual situação da empresa, identificando as áreas que precisam aprimorar. Com a finalidade de medir o trabalho da área de treinamento, devem 
avaliar a atividade de treinamento, o quanto os funcionários estão sendo treinados, o resultado da prática, se estão atingindo as metas ou não, bem como sua eficiência.

Para este estudo, foi realizada uma pesquisa exploratória de natureza qualitativa, que traz informações importantes sobre a necessidade de um plano de treinamento para a Dimona. As entrevistas tiveram um roteiro semiestruturado com os gerentes de cada loja, a coordenadora de Recursos Humanos e os quatro diretores. O formulário de perguntas que guiou o presente trabalho consta nos anexos (ver Anexo I). 


\section{Análise da Situação-Problema e propostas inovação/intervenção/recomendação}

Neste capítulo, serão apresentados as lacunas e desafios identificados na empresa Dimona a partir de entrevistas realizadas pela autora do presente estudo ${ }^{1}$. Essas conversas tiveram intuito de compreender as perspectivas desses gestores em relação aos seus funcionários e as dificuldades que eles encontram no processo de adaptação na empresa. As entrevistas foram realizadas com sete pessoas, sendo quatro gerentes de loja, dois diretores e a coordenadora de Recursos Humanos ${ }^{2}$.

\begin{tabular}{|l|l|l|l|}
\hline Nome & Idade & Função & Área \\
\hline Luis & 53 anos & Diretor & Operações e Compras \\
\hline Igor & 27 anos & Diretor & TI \\
\hline Izabel & 48 anos & Coordenadora & Recursos Humanos \\
\hline Carlos & 41 anos & Gerente de Loja & Vendas \\
\hline Simone & 47 anos & Gerente de Loja & Vendas \\
\hline Cida & 56 anos & Gerente de Loja & Vendas \\
\hline Rodrigo & 27 anos & Gerente de Loja & Vendas \\
\hline
\end{tabular}

(Figura 2 - Perfil dos entrevistados)

\subsection{Treinamento para os novos funcionários e reciclagem para os antigos}

De acordo com todos os entrevistados, desde o início do ano não há treinamento para os novos funcionários, já que o responsável pela prática também é gerente de loja e a empresa se dedicou intensamente ao projeto das Olimpíadas. No único treinamento dado então aos novos

\footnotetext{
${ }^{1}$ Entrevistas realizadas a partir de um formulário de perguntas proposto pela autora. Ver Anexo I.

${ }^{2}$ Para as transcrições completas das entrevistas, ver Anexo II.
} 
funcionários em 2016, foram abordadas as técnicas de venda, a natureza dos produtos e as etapas do processo produtivo, como a transformação de algodão em camisa e as técnicas de estamparia. Para Luis, o diretor de Operações e Compras, os treinamentos eram mais frequentes e melhores quando a empresa tinha apenas duas lojas.

Atualmente não há reciclagem com os antigos funcionários, mas alguns informaram que o projeto existe e só não foi colocado em prática. Como Rodrigo (gerente de loja que ajuda nos treinamentos) está envolvido em vários projetos simultaneamente, fica mais difícil realizar reciclagem.

Para Bohlander \& Snell (2009), as empresas devem ter treinamento com objetivo de contribuir para suas metas gerais. Sendo assim, ao analisar as pessoas, é preciso selecionar quem precisa ser capacitado. Ao levantar a necessidade de treinar, conforme a primeira etapa da Abordagem Sistêmica, é fundamental considerar também as mudanças que ocorrem dentro da organização. No caso específico da Dimona, os treinamentos e o desenvolvimento dos colaboradores não acompanharam o crescimento da empresa, como o Diretor de compras afirmou. Antes de a empresa se tornar o que é hoje, os treinamentos eram melhores e mais eficazes. Dessa forma, se a companhia quiser continuar crescendo, deve julgar a prática de Treinamento e Desenvolvimento tão importante quanto outros projetos, para que assim todos cresçam em sincronia e não haja nenhuma área com defasagem e falhas.

$\mathrm{Na}$ entrevista com gerentes e diretores, houve uma concordância em relação à importância de realizar uma reciclagem com os funcionários antigos para que não passem costumes e vícios errados aos novos. Foi-se constatado também que a empresa, ao longo dos anos, foi se aprimorando, tendo novas técnicas de estamparia e novas malhas - e, por isso, um treinamento constante para todos os funcionários é essencial. Embora tenham concordado sobre a importância de treinar os novos funcionários, todos enfatizaram a urgência em reciclar os antigos.

\subsection{O treinamento oferecido pela Dimona é suficiente para o funcionário desenvolver sua função}

Para dois gerentes de loja, os treinamentos antigos eram suficientes para habilitar o vendedor a realizar suas funções. $\mathrm{Na}$ época em que Rodrigo realizava esse treinamento, o 
trabalho era bem elaborado e ele sabia transmitir o conteúdo de forma clara e fácil, para que os funcionários compreendessem, segundo Carlos.

Já para os outros cinco entrevistados, o treinamento oferecido não era suficiente ainda, justamente por ser algo bem básico. Isso forçava os colaboradores a terem que aprender muita coisa no dia a dia da loja. A coordenadora de RH, por exemplo, acredita que os funcionários precisam ter uma visão mais global do negócio e ir além do aprendizado sobre produtos e técnicas de estamparia. Já Rodrigo, que, como mencionado, além de gerente auxilia nos treinamentos, acredita que ainda há muito o que melhorar, tanto no espaço físico e horário quanto na duração. Ou seja, nesse ponto, ambos acreditam que o pouco treinamento não é suficiente para desenvolver suas funções. O resultado é que os vendedores aprendem no cotidiano das vendas de maneira mais pragmática, respondendo a situações imediatas, mas sem criar uma consciência de venda do produto e da empresa.

A partir das entrevistas, então, é possível constatar que o treinamento, quando oferecido, não é suficiente. Isso propicia uma situação na qual novos funcionários devem aprender sozinhos ou com funcionários antigos, o que é ainda problemático visto que podem adquirir vícios prejudiciais para a empresa. De acordo com Bohlander \& Snell (2009), é necessário treinar e fazer com que esse treinamento cause impacto no desempenho individual e organizacional. Além disso, devido ao fato de um treinamento único não ser suficiente, percebe-se a necessidade de um programa de treinamento contínuo.

Apesar das falhas na capacitação, um dos gerentes afirmou que o treinamento é passado com palavras claras e associado com a rotina dos treinados, o que está ligado a um princípio de aprendizagem da teoria de Bohlander \& Snell (2009), que diz que os treinados têm mais facilidade de aprender quando associam os fatos a assuntos com os quais já estão familiarizados.

\subsection{Desempenho da equipe e o processo de Feedback}

Ainda que cada entrevistado meça o desempenho a partir de perspectivas diferentes, o sistema de medição por cotas diárias dos vendedores é usado por todos para calcular a eficiência de vendas. Para Carlos, o desempenho de sua equipe está bem baixo, pelo fato de o número de vendedores ruins ser maior que o de vendedores bons, o que prejudica a equipe. Além disso, há casos de reclamações dos clientes pela falta de comunicação em relação à entrega de 
encomendas, causando uma insatisfação do comprador com a Dimona. Simone, por sua vez, avalia que a equipe dela está bem estruturada. O desempenho melhorou bastante ao ponto de hoje sua loja ser a que mais vende mercadorias. Ainda que haja problemas, como em qualquer outra loja, as reclamações dos clientes têm sido atendidas e estão diminuindo.

Já Rodrigo, como está envolvido no programa de capacitação, avalia as pessoas de acordo com o que aprendeu nos treinamentos e se há correspondência com a prática diária. Ele também foi o único gerente que mostrou dar feedbacks coletivos, principalmente quando positivos, visando exaltar o funcionário diante da equipe. No caso de Cida, ela afirma que o desempenho mais geral em sua loja é bom, visto que os atendimentos são feitos de forma correta. Enquanto isso, os diretores defenderam a possibilidade de medir a eficácia e o desempenho por meio do número de mercadorias vendidas, clientes atendidos e cotas diárias dos vendedores.

Como Bohlander \& Snell (2009) afirmam, uma das maneiras de medir a necessidade de treinamento é por meio do desempenho da equipe. Nesse caso, os gerentes devem sempre estar atentos para verificar se os funcionários conseguem atingir as metas de produtividade e cuidar das queixas de clientes. A exemplo do que a própria gerência relatou, há hoje na Dimona equipes que ganharam uma melhoria evidente na prestação de serviços e, embora ainda existam

problemas como em qualquer loja, eles são bem menores. Isso demonstra a importância dos gerentes na motivação e no crescimento dos seus times, o que pode ser impulsionado por um treinamento de qualidade.

Certamente, há lojas que necessitam com mais urgência de capacitação do que outras, pelo fato de o desempenho da equipe estar abaixo do esperado e pelo número maior de reclamações de clientes. Ainda de acordo com os autores, além do treinamento, outra prática importante para alcançar melhorias são os feedbacks. Esse tipo de retorno costuma ser motivacional e orienta o trabalho dos funcionários, já que aponta as habilidades que as pessoas estão adquirindo, ou os pontos que carecem de ajustes.

\subsection{Impacto do treinamento no resultado da empresa e na motivação dos funcionários}

Todos afirmaram que, quando há treinamento, o retorno para a empresa é positivo: os erros são menores, evitam-se desperdícios, os clientes ficam mais satisfeitos, desejam retornar e, 
consequentemente, as vendas melhoram. Para Rodrigo, o pouco de treinamento que a empresa já promoveu refletiu que esse é o caminho a ser seguido. Para Izabel, um funcionário bem treinado exercerá suas funções da forma correta e trará menos problemas.

Ao avaliar a motivação dos funcionários, os entrevistados seguiram na mesma linha de raciocínio ao afirmar que um sistema de treinamento contínuo seria positivo para as equipes. Isso ocorreria principalmente porque a Dimona está em um ramo bem distinto, com muitas especificidades. Como o próprio Rodrigo afirmou, quando o empregado sabe que terá um treinamento para se familiarizar, ele se sente mais motivado e acolhido. Porém, como Igor alerta, essa motivação ocorre em médio prazo, já que os treinamentos sempre foram realizados no fim do expediente, gerando insatisfação e eficácia reduzida. Para Luis, a motivação tem duração muito curta. Ele acredita que isso se deve ao fato de haver poucos treinamentos, mas que um programa de aperfeiçoamento contínuo talvez fosse capaz de incentivar uma atuação mais ativa dos funcionários.

De acordo com as entrevistas, quando há treinamento a produtividade é melhor, aumentase substancialmente o comprometimento do funcionário com a empresa e evitam-se falhas. Segundo Bohlander \& Snell (2009), como a produtividade da empresa e a motivação dos funcionários são melhores no período de capacitação, existe aí mais um motivo para a empresa treinar constantemente seus funcionários. Além disso, pessoas motivadas, autodisciplinadas e conscientes têm maiores chances de perceber a ligação entre o esforço que empregam no treinamento e o melhor desempenho no trabalho.

\subsection{Sugestões para aprimorar o treinamento}

A principal sugestão é que existam treinamentos contínuos, bem estruturados e em horários melhores, evitando o fim do expediente. Deve-se propiciar ainda um espaço adequado para essa prática, trazendo instrutores especializados no assunto abordado e promovendo o acompanhamento contínuo por parte de uma pessoa focada nos treinamentos.

Outro ponto é que os gerentes se mostraram insatisfeitos por não terem tido treinamento quando promovidos de vendedores a gerentes. Eles sugeriram que também houvesse treinamento gerencial para que se capacitassem cada vez mais, pois tudo o que aprenderam para chegar aonde estão foi no dia a dia. Uma questão que enfatizaram foi a reciclagem dos antigos funcionários, 
pelo fato de alguns deles prejudicarem os novos, ensinando formas erradas de atuar como vendedor. Outro meio de reduzir esse problema seria treinar os funcionários antes que comecem a atuar nas lojas - um mês de dedicação intensiva.

De acordo com o diretor de Operações e Compras, a companhia está procurando uma empresa terceirizada ou até um consultor da área, pois foi percebido que não é possível ter seis lojas e continuar crescendo sem treinar os funcionários.

As sugestões dadas pelos entrevistados se encaixam na teoria de Bohlander \& Snell (2009), segundo a qual após levantar as necessidades de treinar a equipe, é preciso elaborar o programa de treinamento focado nos objetivos instrucionais, desenhando-se o resultado esperado, as habilidades e os conhecimentos a serem adquiridos. Outro fator importante para um bom treinamento é ter um bom treinador, que revele conhecimento do assunto e saiba transmitir os conceitos de forma clara, de acordo com as demandas e o perfil da turma. Após essa fase implementa-se o programa, quando a empresa deve escolher também o melhor tipo de treinamento. Conforme o que foi registrado nas entrevistas, seria interessante fazer um jobrotation, no qual o vendedor passaria por todas as lojas, inclusive o Centro de Distribuição, para ganhar uma visão global da Dimona.

Além disso, as conversas mostraram ser interessante trazer pessoas do mercado especializadas em treinamento para vendedores do varejo. Isso seria parte do treinamento formal interno (Lacombe, 2005), no qual a empresa pode convidar pessoas de fora ou dentro da organização para relatar suas experiências e transmitir conteúdo prático. O mais importante é oferecer treinamento contínuo, com uma pessoa focada em acompanhar todo o processo.

Visando ao alcance do objetivo deste trabalho, apresenta-se a seguir uma proposta de treinamento para os funcionários da Dimona, à luz do modelo de Bohlander \& Snell (2009).

Plano de Treinamento Dimona:

i) Levantamento de necessidade

Os entrevistados concordaram que a falta de treinamento para antigos e novos funcionários é por si só um motivo relevante para estruturar um plano de treinamento. Algumas lojas apresentam mais reclamações que outras, porém, todas têm seus problemas. A loja em que Simone é gerente, por exemplo, ainda que a produtividade 
tenha aumentado, não deixou de ter questões a resolver. No caso da Dimona, todos os vendedores deverão passar por treinamento, sendo no primeiro momento divididos entre novos e antigos para que "aprendam a falar a mesma língua".

ii) Projeto

Ao elaborar o projeto de treinamento, deve-se considerar o ambiente que propiciará o melhor aprendizado, como uma sala dentro da própria Dimona. De acordo com as entrevistas, o fato de o treinamento ser no fim do expediente faz com que não seja produtivo e eficaz. Logo, o primeiro item a ser mudado nesse plano de treinamento é o horário, que deve ser no período da manhã.

Outro fator importante seria que os novos funcionários participassem de um treinamento intensivo antes de entrarem nas lojas, para não aprenderem os vícios dos funcionários antigos. Então, seria interessante que nos primeiros quinze dias eles se dedicassem apenas aos treinamentos, passando, somente depois dessa fase, ao trabalho no ponto de venda. Após os quinze dias iniciais, poderiam ser oferecidas seções semanais de capacitação para completar o aprendizado.

O estágio inicial do treinamento proposto neste trabalho tem o objetivo de eliminar práticas prejudiciais dos funcionários antigos e ensinar aos novos o que é a Dimona. Para isso, nesse primeiro momento, as pessoas seriam separadas por grupos de colaboradores novos e antigos. Nos estágios seguintes, a sugestão é que funcionários com diferentes tempos de casa participem das mesmas capacitações, compartilhando experiências em treinamentos comportamentais, motivacionais, desenvolvimento de habilidades, de liderança, de comunicação, entre outros.

O treinamento dos funcionários antigos vai demandar maior organização do tempo, pois não há como deixar as lojas sem vendedores. Então, eles serão divididos em grupos e treinados na parte da manhã uma vez por semana, durante dois meses. Caso o treinador entenda que alguma turma precise prolongar a capacitação, poderá sugerir mais tempo de aula ou aumentar o foco sobre determinado tema.

Antes de iniciar o treinamento em si, é necessário desenhar as metas que devem ser atingidas e pensar sobre os conhecimentos e habilidades desejados para os vendedores. Isso facilitará a avaliação ao término de cada processo. 
De acordo com Bohlander \& Snell (2009), a vontade de aprender e a motivação influenciam substantivamente os treinamentos. Como Igor afirmou, porém, há funcionários que não gostariam de estar presentes porque não apreciam o horário marcado, nem têm o costume de serem treinados. A resposta a essa reação negativa está na adequação do horário e na transformação dos treinamentos em uma prática regular. Certamente, dessa forma a visão dos funcionários se tornaria mais positiva.

Além disso, como há vendedores da Dimona que não necessariamente completaram o Ensino Médio, seria relevante que o responsável pelo treinamento fosse uma pessoa acessível, com metodologia de ensino didática e clara, ressaltando exemplos que estão no dia a dia das turmas, para facilitar o aprendizado.

A partir da entrevista feita com o diretor de Operações e Compras, identificou-se que a Dimona está disposta a contratar um consultor ou até uma empresa terceirizada, que se responsabilize pelos treinamentos e acompanhe diariamente os funcionários.

iii) Implementação

Acredita-se que o tipo de treinamento mais adequado para a Dimona seria o formal interno, ministrado tanto por pessoas da própria empresa quanto de fora. Mesmo que os vendedores sejam divididos entre novos e antigos, os temas abordados nos treinamentos são: técnica de vendas, o que é vendido na Dimona, os tipos de estampa, a história da empresa e como usar o sistema.

Esses assuntos, porém, seriam administrados com ênfases diferentes, contemplando desde funcionários que não têm nenhuma familiaridade com a Dimona aos que, embora já atuem na empresa, possuam modos errados de abordar o cliente e explicar sobre as diferentes formas de estamparia - a falha na explicação prejudica até quando esse funcionário mais experiente ensina aos vendedores novatos.

Diante de um grupo com vivências distintas, o treinador deverá transmitir o conteúdo de acordo com o perfil do grupo que está sendo treinado, com exemplos e enfoques específicos para cada.

iv) Avaliação 
No início do treinamento, a empresa terá desenhado as habilidades e técnicas que deseja oferecer às equipes. Então, no momento de avaliação da eficácia do curso, estará apta a comparar se as expectativas em relação ao treinamento foram cumpridas. Outra forma seria considerar a motivação dos funcionários, se os desperdícios diminuíram, se houve aumento de produtividade e, por fim, se houve uma diminuição no número de reclamações. 


\section{Conclusões e Contribuição Tecnológica/Social}

A partir da análise das entrevistas realizada pela autora deste trabalho, é plausível defender que a empresa Dimona possui uma grande necessidade de treinar seus vendedores - objeto deste estudo. Além disso, foi possível constatar que essa necessidade não se limita apenas aos funcionários que lidam diretamente com a venda, mas a diretores, gerentes e até funcionários que atuam por trás do negócio, como os estoquistas, prensadores, entre outros. Nesse sentido, acredito que os setores mais sensíveis a treinamento seriam, além dos vendedores, os gerentes e os diretores.

Os treinamentos para os gerentes serão essenciais, especialmente pelo fato de os próprios terem afirmado que nunca passaram por nenhum treinamento quando promovidos à gerência. Diante de uma ausência de acompanhamento nessa transição, consequentemente, as entrevistas revelaram que muitos gerentes não têm o perfil para atuar nesse tipo de cargo, e, mais grave, muitos não têm um conhecimento da própria equipe. Isso é, evidentemente, uma decorrência de esses profissionais nunca terem tido um treinamento mais contínuo. Muitos foram promovidos por se mostrarem ótimos vendedores, mas, como já foi argumentado aqui, não necessariamente bons vendedores serão bons gerentes.

O treinamento para diretores também se mostra crucial. Afinal, não é eficiente treinar a equipe de vendas se a diretoria age de outra forma e dá ordens distintas do que foi passado no treinamento. Uma situação que pode acontecer, por exemplo, é um dos diretores, que tem sua sala no mesmo andar que o da loja, eventualmente dar ordens em tom alto a partir da sua sala - assustando clientes. Esse é mais um dos fatores que refletem a necessidade que diretores também sejam treinados e reeducados de acordo com a cultura que a nova geração está propondo trazer.

Ademais, de acordo com as entrevistas, observou-se uma maior necessidade de treinamento dos vendedores antigos. Os entrevistados apresentaram argumentos similares, 
constatando os vícios e modos errados de alguns desses vendedores na abordagem do cliente. O mais grave, porém, é que o comportamento deles influencia substantivamente os recém-chegados. Como alguns estão há anos na empresa, os novos funcionários se adequam a essa prática, acreditando ser a correta. Contudo, essa é mais uma prática que faz com que os vendedores prejudiquem a empresa, demonstrando a grande necessidade de treiná-los.

A partir dessa pesquisa, é possível argumentar que grande parte da dificuldade em promover vendedores para o cargo de gerentes está intimamente associada à falta de treinamento e também ao fato dos diretores mostrarem não ter uma visão sistêmica da empresa, na qual deveriam entender a companhia como um todo, com o intuito de alcançar um objetivo, portanto entenderiam e valorizariam ainda mais as práticas de RH, mas no presente momento esse é um grande desafio para a família, principalmente para a geração mais velha compreender a importância de tal fato. Muitos entrevistados e os próprios vendedores mencionam dificuldades que poderiam ser facilmente reduzidas com uma prática constante de aperfeiçoamento.

Com este estudo e o treinamento adequado, a empresa conseguirá encontrar diversas falhas responsáveis pelos danos à companhia, bem como os elementos que dificultam a promoção de vendedores. Um exemplo que poderia ser apontado é a ausência de um plano de carreira, desmotivando o funcionário a estar ali, justamente por não saber se irá conseguir crescer dentro desse ambiente, ainda mais por ser uma empresa familiar ou até mesmo poderia ser feito um plano de carreira em Y que é um plano próprio para funções mais técnicas que tem como pressuposto a mobilidade e o crescimento profissional do funcionário.

Outro motivo que pode ser mencionado seria a falha na contratação, quando a empresa absorve pessoas fora do perfil adequado, o que se traduz em um gasto muito grande que poderia ser evitado. Há ainda a questão do clima organizacional, que se não receber a atenção necessária é capaz de desanimar bons vendedores. É por isso que, a partir deste trabalho, argumento que com um consolidado plano de treinamento os diretores da Dimona estarão aptos a notar a importância das práticas de Recursos Humanos dentro da empresa, compreendendo que elas não são apenas despesas, mas benefícios à companhia. 
Para tanto, a partir do momento em que a Dimona começar a investir na gestão de pessoas, estar disposta a ter uma equipe para essa área e desenvolver práticas de $\mathrm{RH}$, será necessário fazer uma pesquisa com todos os funcionários, incluindo os vendedores, estoquistas, operador de caixa, entre outros, para assim entender as suas expectativas, o que os motiva e não só o que os gerentes e a diretoria pensam.

Diante do exposto, meu objetivo, ao entrar na Dimona, é estruturar a área de Recursos Humanos. Para tanto, é essencial que esse setor conte com uma equipe, visto que disponibilizar apenas um profissional para atender uma empresa com cerca de duzentos funcionários é algo inviável. Não é à toa que a coordenadora de RH investe muito tempo em recrutamento e seleção, mas não possui agenda suficiente para estruturar novas práticas. Além disso, e não menos importante, quero mostrar e fazer com que essa área seja tão relevante quanto as demais e fazer com que a diretoria dê o valor que se deve, acredito que para isso ocorrer, será um grande desafio, visto que a geração mais velha não dá a devida importância a tal área.

Afinal, o RH é essencial para propiciar reconhecimento, treinamento e motivação, possibilitando que os funcionários se identifiquem com a identidade corporativa. Uma vez motivados, esses funcionários darão o melhor de si, o que culminará necessariamente no crescimento da empresa.

Por fim, este estudo foi relevante para apontar os desafios e dificuldades da Dimona no que concerne à capacitação dos seus funcionários. Tradicionalmente, a cultura da empresa - ainda fortemente influenciada pela geração mais velha - não se preocupava em oferecer um treinamento mais sistêmico aos seus funcionários, pois isso era compreendido como um custo. Contudo, gradativamente, os desafios contemporâneos comprovam que esse tipo de custo é, na verdade, um investimento, como pretendi argumentar. Durante a pesquisa em campo, todos os entrevistados foram unânimes em reconhecer que a estrutura de treinamento mais contínuo poderia ser mais interessante para desenvolver seus funcionários, atender melhor o cliente e, consequentemente, aumentar a competitividade da empresa no mercado.

Apesar disso, pouco foi realizado nesse sentido e o que se observa é a repetição de maus hábitos dos vendedores antigos por parte dos novos, bem como promoções de cargo que não preparam o funcionário para as novas atividades. Por isso, o esforço principal 
deste trabalho foi o de argumentar não só que os vendedores precisam de treinamento, mas que esse treinamento seja parte de uma estrutura de capacitação de funcionários mais contínua, conferindo ao RH o protagonismo nesse processo. Uma vez que essas práticas se naturalizem, o que se vislumbra é o aumento da motivação dos funcionários, a redução de desperdícios e, evidentemente, o aumento das vendas e lucro da Dimona. 


\section{Referências Bibliográficas}

Associação Brasileira de Treinamento e Desenvolvimento (ABTD); MOT Treinamento e Desenvolvimento (MOT). O Retrato do Treinamento no Brasil: 2013/2014. São Paulo: T\&D Inteligência Corporativa, 2013. Disponível em: <http://portal.abtd.com.br/Conteudo/Material/Arquivo/PesquisaABTD20132014.pdf> Acesso em: 07 jul. 2016.

BECKER, Eduardo. Retenção de talentos no varejo - como evitar que seu planejamento não morra na praia. Administradores website, dez 2013. Disponível em: <http://www.administradores.com.br/artigos/marketing/retencao-de-talentos-no-varejo-comoevitar-que-seu-planejamento-nao-morra-na-praia/74483/>. Acesso em: 02 jun. 2016.

BOHLANDER, George; SNELL, Scott. Administração de Recursos Humanos. 14 ${ }^{\mathrm{a}}$ Ed. São Paulo: Cengage Learning, 2011.

CHIAVENATO, Idalberto. Gestão de Pessoas. $3^{\mathrm{a}}$ Ed. Rio de Janeiro: Elsevier, 2010.

DELOITTE. Pesquisa: Estratégias para o varejo brasileiro. Reflexões sobre os anseios do consumidor. São Paulo: Deloitte, 2010. Disponível em: <http://deloitteoracle.com/uploads/stw_pdfcart/Retail_Reflections_Brazil_Portugues1398094367.pdf>. Acesso em: 04 jun. 2016.

GIL, Antonio Carlos. Gestão de pessoas: enfoque nos papéis profissionais. São Paulo: Atlas, 2001.

Instituto Brasileiro de Geografia e Estatística (IBGE). Pesquisa Mensal de Emprego: Síntese de indicadores Fevereiro - 2016. Rio de Janeiro, 2016. Disponível em: < ftp://ftp.ibge.gov.br/Trabalho_e_Rendimento/Pesquisa_Mensal_de_Emprego/fasciculo_indicado res_ibge/2016/pme_201602pubCompleta.pdf >. Acesso em: 04 jun. 2016. 
_. Pesquisa Mensal de Comércio: Síntese de indicadores Março - 2016. Rio de Janeiro, 2016. Disponível

em: <ftp://ftp.ibge.gov.br/Comercio_e_Servicos/Pesquisa_Mensal_de_Comercio/Fasciculo_Indicado res_IBGE/pmc_201603caderno.pdf >. Acesso em: 04 jun. 2016.

Instituto para Desenvolvimento do Varejo (IDV). Varejo em Números. IDV website, s.d. Disponível em:< http://www.idv.org.br/varejo-em-numeros/>. Acesso em: 21 jun. 2016.

IVANCEVICH, John M. Gestão de Recursos Humanos. 10 ${ }^{\text {a }}$ Ed. São Paulo, SP: McGraw - Hill, 2008.

KOTLER, Philip. Administração de Marketing: análise, planejamento, implementação e

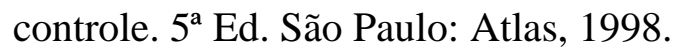

LACOMBE, Francisco. Recursos Humanos: Princípios e Tendências. São Paulo: Saraiva, 2005.

LAMPER, Adriana. Rotatividade é o desafio para o varejo. Jornal do Comércio, 26 de out. 2015.

Disponível

em: <http://jcrs.uol.com.br/_conteudo/2015/10/cadernos/empresas_e_negocios/462508-crise-acelerarotatividade-no-varejo.html >. Acesso em: 05 de out. 2016.

LURDERS, G. Varejo: O motor da economia brasileira. Revista Exame, 12 de jun. 2014. Disponível em: <http://exame.abril.com.br/negocios/noticias/o-futuro-do-varejo>. Acesso em: 04 jun. 2016.

MOTTA, Arthur. A atuação do Varejo, abr. 2014. Disponível em: <http://www.gsmd.com.br/pt/eventos/a-atuacao-do-varejo-moderno/apagao-de-mao-de-obra-novarejo>. Acesso em: 02 jun. 2016.

VAROTTO, Luís Fernando. História do Varejo. GV-Executivo, vol. 5, n.1, fev-abr 2006. Disponível em: <http://bibliotecadigital.fgv.br/ojs/index.php/gvexecutivo/article/viewFile/34379/33176>. Acesso em: 19 set. 2016.

SERVIÇO BRASILEIRO DE APOIO ÀS MICRO E PEQUENAS EMPRESAS (SEBRAE). Em Dez Anos, Os Valores da Produção Gerada pelos Pequenos Negócios Saltaram de R\$ 144 
bilhões para R\$ 599 Bilhões. Sebrae website, 2014. Disponível em: <http://www.sebrae.com.br/sites/PortalSebrae/ufs/mt/noticias/micro-e-pequenas-empresasgeram-27-do-pib-do-brasil,ad0fc70646467410VgnVCM2000003c74010aRCRD>. Acesso em: 19 set. 2016. 


\section{ANEXO I}

(Formulário de entrevistas - elaborado pela autora)

1) Quais são os tipos de treinamento oferecidos atualmente pela Dimona aos novos funcionários?

2) Existe algum programa de reciclagem para os funcionários antigos?

3) Você considera o treinamento oferecido pela Dimona suficiente para o funcionário desenvolver sua função adequadamente? Por quê?

4) Como você mede o desempenho de sua equipe?

5) Qual o processo de feedback que você utiliza com a sua equipe?

6) Qual o impacto do treinamento no resultado da empresa?

7) Qual o impacto do treinamento na motivação do funcionário?

8) O que você sugere para aprimorar o treinamento dos funcionários? 


\section{ANEXO II}

(Transcrição das entrevistas com funcionários da empresa Dimona sobre avaliação do programa de treinamento a partir do formulário do Anexo I)

\section{Entrevista 01:}

Entrevista concedida por Carlos (Gerente da Loja 1) à autora do presente trabalho em 25 out. 2016, Rio de Janeiro (RJ).

1) Quais são os tipos de treinamento oferecidos atualmente pela Dimona aos novos funcionários?

R: Nenhum, os treinamentos estão parados. Antes havia um treinamento com o Rodrigo, porém, no momento não há.

2) Existe algum programa de reciclagem para os funcionários antigos?

R: Não existe. Há um tempo o Rodrigo tentou implementar esse projeto, mas por ele ajudar com várias tarefas não deu prosseguimento.

3) Você considera o treinamento oferecido pela Dimona suficiente para o funcionário desenvolver sua função adequadamente? Por quê??

R: Sim, se for bem implementado. Os treinamentos que o Rodrigo dava eram bem elaborados. Ele consegue usar palavras simples para ensinar aos vendedores as técnicas de venda, estampa e tipos de malha.

4) Como você mede o desempenho de sua equipe?

R: Bem baixo. Uma parte da equipe é bem fraca e composta por vendedoras que geram muitos problemas, em vez de vender e trazer soluções. O resultado é que as vendas caíram.

5) Qual o processo de feedback que você utiliza com a sua equipe?

R: Os feedbacks costumam ser individuais, tanto os positivos - quando a vendedora se destaca nas vendas - quanto os negativos, quando seu atendimento é ruim. Faço individualmente porque algumas pessoas da equipe não recebem isso bem. 


\section{6) Qual o impacto do treinamento no resultado da empresa?}

R: Quando há treinamento e incentivos da diretoria, o impacto é muito bom, as vendas melhoram e há maior identificação dos funcionários com a empresa.

\section{7) Qual o impacto do treinamento na motivação do funcionário?}

R: É positivo para quem quer que seja positivo. Até para ir para o treinamento a pessoa tem que ir com vontade de aprender.

\section{8) O que você sugere para aprimorar o treinamento dos funcionários?}

R: Primeiro, tenho que sugerir que haja treinamentos. Deveria haver um treinamento bem mais forte para os vendedores. Acredito que deveria começar com um treinamento gerencial, pois nunca tiveram nenhum. Depois um destinado à área de vendas, que é o pulmão da loja, por onde entra o dinheiro, por meio dos clientes. Existem vendedores que estão nas lojas sem treinamento e sua forma de aprender é no dia a dia. Antes era um treinamento diário, aprendiam mais sobre a empresa, tudo o que existe por trás da companhia, desde do algodão até a matéria-prima pronta na casa do cliente. $O$ treinamento faz com que o funcionário aprenda a essência da empresa, não apenas para ficar atrás do balcão. Vendedor da Dimona tem que ser muito além de balconista.

\section{Entrevista 02:}

Entrevista concedida por Izabel (Coordenadora de RH) à autora do presente trabalho em 25 out. 2016, Rio de Janeiro (RJ).

1) Quais são os tipos de treinamento oferecidos atualmente pela Dimona aos novos funcionários?

R: O treinamento aborda temas como: integração, quando falamos da empresa; normas; e a questão dos produtos, que era com o Rodrigo e acontecia no início do ano. Devido ao projeto das Olimpíadas, acabou que não houve treinamento desde o começo de 2016. Aliado a isso, a rotatividade diminui bastante e quase não temos tido funcionários novos, então nessa época não estamos tendo capacitação.

2) Existe algum programa de reciclagem para os funcionários antigos? 
R: Ainda não existe, mas já teve a ideia do projeto.

3) Você considera o treinamento oferecido pela Dimona suficiente para o funcionário desenvolver sua função adequadamente? Por quê??

R: Não, com certeza não. Temos que reforçar as técnicas de venda e atendimento, não apenas explicar sobre o produto. $\mathrm{O}$ vendedor precisa ter uma visão mais global.

4) Como você mede o desempenho de sua equipe?

R: Apenas pelo feedback que os gerentes e as próprias equipes me passam, também pelo fato de a rotatividade ter diminuído.

5) Qual o processo de feedback que você utiliza com a sua equipe?

R: Feedback pessoal, os gerentes me passam as informações sobre a equipe e se necessário chamo o funcionário para uma conversa.

6) Qual o impacto do treinamento no resultado da empresa?

R: Todo o impacto, uma pessoa bem treinada vai desenvolver suas funções melhor.

7) Qual o impacto do treinamento na motivação do funcionário?

$\mathrm{R}$ : Todo o impacto, pois, com o treinamento, o funcionário de vendas consegue ver como seu resultado poderá ser melhor, o que significa salário maior no fim do mês. O retorno financeiro para eles é o mais importante.

8) O que você sugere para aprimorar o treinamento dos funcionários?

R: Ter uma sala adequada e um orçamento para treinamentos. $\mathrm{O}$ horário é outro fator importante, pois no fim do expediente o funcionário não tem a mesma concentração e não vê a hora de ir para casa. Então, de manhã seria melhor e mais eficaz.

\section{Entrevista 03:}

Entrevista concedida por Luis (Diretor de Operações e Compras) à autora do presente trabalho em 25 out. 2016, Rio de Janeiro (RJ). 
1) Quais são os tipos de treinamento oferecidos atualmente pela Dimona aos novos funcionários?

R: Hoje não há, mas quando havia treinamento era bem básico. Falava sobre os produtos e o atendimento ao cliente. Depois, os novos funcionários acompanhavam uma ou duas semanas os vendedores mais experientes para aprender. Antigamente, quando a empresa tinha duas lojas, era bem melhor.

2) Existe algum programa de reciclagem para os funcionários antigos?

R: Não!

3) Você considera o treinamento oferecido pela Dimona suficiente para o funcionário desenvolver sua função adequadamente? Por quê?

R: Não. Pelo fato de o treinamento ser bem básico, o novo funcionário não se adequa para desenvolver a sua função.

4) Como você mede o desempenho de sua equipe?

R: Conseguimos medir pela quantidade de peças vendidas, quantidade de pessoas atendidas, se os vendedores batem as cotas ou não. Os primeiros colocados são premiados.

5) Qual o processo de feedback que você utiliza com a sua equipe?

R: Como minha sala fica no andar da loja, participo muito das vendas e dos atendimentos. Com isso, ajudo bastante. $\mathrm{O}$ feedback que dou ocorre nesses momentos.

6) Qual o impacto do treinamento no resultado da empresa?

$\mathrm{R}$ : Menos problemas de desperdício e de mau atendimento. Isso reduz a chance de o cliente ir embora, o que pode aumentar as vendas e a satisfação dele com a empresa.

7) Qual o impacto do treinamento na motivação do funcionário?

R: Sempre que fizemos treinamentos, os funcionários se sentiam mais motivados, mas a duração da motivação costumava ser muito curta. O problema, porém, é que os treinamentos eram dados poucas vezes e não eram contínuos. 


\section{8) O que você sugere para aprimorar o treinamento dos funcionários?}

R: Estamos buscando isso com uma empresa terceirizada, um consultor para que possa nos ajudar a implementar esse projeto. Vimos que não tem como ter seis lojas e não treinar os funcionários.

\section{Entrevista 04:}

Entrevista concedida por Rodrigo (Gerente de loja 2) à autora do presente trabalho em 25 out. 2016, Rio de Janeiro (RJ).

1) Quais são os tipos de treinamento oferecidos atualmente pela Dimona aos novos funcionários?

R: Fazemos uma preparação para eles conhecerem os produtos. Há uma apresentação básica do processo que vai desde o colhimento do algodão à feitura da malha e todas as etapas até se transformar em uma camiseta; a cultura da empresa; os procedimentos de venda e sistemas; técnicas de estamparia. Desde o início do ano não há treinamento, devido ao projeto das Olimpíadas, que fez com que a gente não tivesse tempo para outros projetos.

\section{2) Existe algum programa de reciclagem para os funcionários antigos?}

R: Hoje em dia não tem, mas existe o projeto, pois os funcionários antigos têm sua forma de atender e seus vícios.

3) Você considera o treinamento oferecido pela Dimona suficiente para o funcionário desenvolver sua função adequadamente? Por quê??

R: Não, ainda tem muito a melhorar, como o tempo dedicado, o espaço usado e a forma de transmitir o conteúdo, pois os funcionários em treinamento já estão nas lojas e aprendem certas coisas com funcionários antigos que não são certas.

\section{4) Como você mede o desempenho de sua equipe?}

R: Medimos após o treinamento, avaliando como o funcionário escolhe a melhor técnica de estampa de acordo com o que o cliente deseja; se o funcionário conhece bem os produtos que a empresa oferece; se tem facilidade de utilizar o sistema, onde lança os pedidos dos 
consumidores; se tem uma postura mais agressiva de venda; se tem o costume de ficar na porta da loja sempre abordando os consumidores; e se está disposto a sugar o conhecimento aprendido no treinamento.

5) Qual o processo de feedback que você utiliza com a sua equipe?

R: Os feedbacks negativos são individuais, já os positivos fazemos com a equipe toda para exaltar o funcionário.

6) Qual o impacto do treinamento no resultado da empresa?

R: Acredito que seja muito grande. Quando implementamos os treinamentos, a questão do atendimento melhorou muito, mostrando que o caminho é esse.

7) Qual o impacto do treinamento na motivação do funcionário?

R: É total. Nosso segmento é muito complexo. Quando o funcionário entra na loja e vê todos os tipos de malha e estampa, a vontade é desistir. Quando sabe que terá um treinamento, no entanto, ele se sente mais acolhido e motivado

8) O que você sugere para aprimorar o treinamento dos funcionários?

R: Acredito que o novo funcionário deveria passar por um treinamento intensivo antes de começar a vender nas lojas, para assim não ter chances de aprender com os vícios dos vendedores antigos, o que atrapalha o entendimento dos conceitos que desejamos transmitir. O ideal é um programa de treinamento bem estruturado e desenhado, com técnicas adequadas.

\section{Entrevista 05:}

Entrevista concedida por Cida (Gerente de Loja 3) à autora do presente trabalho em 25 out. 2016, Rio de Janeiro (RJ).

1) Quais são os tipos de treinamento oferecidos atualmente pela Dimona aos novos funcionários?

R: Quando entravam, os funcionários tinham um treinamento de vendas com o Rodrigo, que durava duas semanas, mas no momento não tem nada. 
2) Existe algum programa de reciclagem para os funcionários antigos?

R: Não, sempre cobrei isso dos diretores e nunca teve.

3) Você considera o treinamento oferecido pela Dimona suficiente para o funcionário desenvolver sua função adequadamente? Por quê??

R: O treinamento que os funcionários recebiam sobre sistema bastava para utilizá-lo. O básico que aprendiam para atender, porém, viam e ainda veem muito no dia a dia.

4) Como você mede o desempenho de sua equipe?

R: O desempenho dos vendedores é bom, já que os atendimentos são bons.

5) Qual o processo de feedback que você utiliza com a sua equipe?

R: No momento em que vejo o vendedor atendendo de forma errada, espero o atendimento acabar, chamo o funcionário no canto e converso. Os próprios feedbacks positivos são individuais, pois como a loja é menor dá tempo de falar individualmente ao longo do dia.

6) Qual o impacto do treinamento no resultado da empresa?

R: Quando tem, o impacto é bom.

7) Qual o impacto do treinamento na motivação do funcionário?

R: Quando havia, os funcionários se sentiam mais motivados, com mais vontade de vender e identificados com a empresa.

8) O que você sugere para aprimorar o treinamento dos funcionários?

R: Sugiro que tenha treinamento com pessoas especializadas em técnicas de vendas, além da reciclagem para os antigos funcionários.

\section{Entrevista 06:}

Entrevista concedida por Igor (Diretor de TI) à autora do presente trabalho em 25 out. 2016, Rio de Janeiro (RJ). 
1) Quais são os tipos de treinamento oferecidos atualmente pela Dimona aos novos funcionários?

R: Nenhum, eles recebem uma apostila. Acredito que eles aprendam na marra.

2) Existe algum programa de reciclagem para os funcionários antigos?

R: Ainda não, mas existe o projeto.

3) Você considera o treinamento oferecido pela Dimona suficiente para o funcionário desenvolver sua função adequadamente? Por quê?

R: Não, já que praticamente não há treinamento. Então, não tem como o funcionário desenvolver sua função de forma adequada. O que acaba acontecendo é que ele aprende no dia a dia da loja, e isso não é o ideal.

4) Como você mede o desempenho de sua equipe?

R: Por meio das cotas diárias que as vendedoras recebem.

5) Qual o processo de feedback que você utiliza com a sua equipe?

R: Com a minha equipe de TI temos reuniões semanais. Nas lojas, os gerentes são responsáveis por dar o feedback.

6) Qual o impacto do treinamento no resultado da empresa?

R: Quando a gente treina outras áreas, como o Call Center, o resultado é positivo. Mas as lojas ainda não têm treinamento. Se tivessem, acredito que seria positivo tanto na melhora das vendas quanto na forma de o funcionário enxergar a empresa.

7) Qual o impacto do treinamento na motivação do funcionário?

R: Acredito que em médio prazo é motivador. Quando havia treinamento, porém, era no fim do expediente, o que deixava os funcionários insatisfeitos.

8) O que você sugere para aprimorar o treinamento dos funcionários? 
R: Tem que fazer parte da rotina, ter continuidade. Eles vão entender que é necessário, e não uma perda de tempo. Acho que também seria bom rodar pela empresa toda, passar uns dias no Centro de Distribuição, no estoque, na estamparia, para assim entender como tudo funciona.

\section{Entrevista 07:}

Entrevista concedida por Simone (Gerente de Loja 4) à autora do presente trabalho em 25 out. 2016, Rio de Janeiro (RJ).

1) Quais são os tipos de treinamento oferecidos atualmente pela Dimona aos novos funcionários?

R: O Rodrigo cuida dessa parte, mas muitas vezes a empresa não consegue dar continuidade à prática, pois ele exerce outras funções. Então, acaba que o treinamento fica de lado, como está acontecendo agora. Em 2016, a última vez que teve capacitação foi no início do ano. Acho que deveria ter esse treinamento com uma regularidade maior.

2) Existe algum programa de reciclagem para os funcionários antigos?

R: Não!

3) Você considera o treinamento oferecido pela Dimona suficiente para o funcionário desenvolver sua função adequadamente? Por quê?

R: Não, eles aprendem muito na prática. Quando mudei de vendedora para gerente não tive nenhum treinamento. Aprendi no dia a dia, na prática. Com meus erros, fui aprendendo onde devia mudar.

4) Como você mede o desempenho de sua equipe?

R: Acredito que consegui formar uma boa equipe, talvez a melhor comparando com as outras lojas. Temos problemas como qualquer loja, mas em termos de equipe formamos uma boa. Nosso desempenho melhorou, nosso total de vendas é maior comparado a outras lojas, a reclamação dos clientes diminuiu também. 


\section{5) Qual o processo de feedback que você utiliza com a sua equipe?}

R: Tanto o positivo quanto o negativo costumo falar individualmente. Quando é preciso chamar a atenção, eu chamo. Quando devo destacar o funcionário por estar vendendo bem, também mostro a importância dele para a equipe.

6) Qual o impacto do treinamento no resultado da empresa?

R: Poderia ser melhor, caso houvesse treinamentos com os novos e velhos funcionários. Para os novatos, seria importante e, para os antigos, mil vezes mais, pois os antigos têm vícios e costumes errados que acabam passando para os novos.

\section{7) Qual o impacto do treinamento na motivação do funcionário?}

R: Acho que o impacto é quando o funcionário recebe o treinamento e vê que pode ganhar a vida fazendo uma coisa legal. Além disso, ele vê a satisfação do cliente saindo da loja. O funcionário tem que vender isso e entender o quanto isso é importante para o cliente. $O$ treinamento tem que mostrar esse outro lado: que estamos realizando sonhos. Isso pode fazer toda diferença para o funcionário que entende a importância de ver o cliente satisfeito.

\section{8) O que você sugere para aprimorar o treinamento dos funcionários?}

R: Ter regularidade; reciclagem dos funcionários antigos; escolher o horário do treinamento na parte da manhã, e não perto da hora saída; ter um treinamento para os gerentes, pois não tivemos um processo desse para virar gerente. E, ainda, revezar os funcionários nas lojas para conhecer as outras lojas, como cada uma funciona, suas diferenças e, principalmente, fazer com que todos falem a mesma língua. 